\title{
Acute-phase proteins and serum immunoglobulins in ankylosing spondylitis
}

\author{
M. R. LAURENT AND G. S. PANAYI \\ From the Departments of Medicine and Rheumatology, Guy's Hospital Medical School, London Bridge, \\ SE1 9RT
}

SUMMARY The erythrocyte sedimentation rate (ESR) and the serum acute-phase proteins (APP), C-reactive protein (CRP), fibrinogen, 9th component of complement (C9), and $\alpha_{1}$ antitrypsin were measured on 231 occasions in 80 patients with ankylosing spondylitis and compared with those in 30 controls. APP levels did not correlate with clinical assessment of disease activity. However, there were significant correlations between CRP, C9, and fibrinogen $(p=<0 \cdot 01)$, suggesting that these APP may be more reliable indicators of disease activity. The mean values of the APP in those patients with a peripheral arthritis were significantly higher than in those with pelvospondylitis alone for $\operatorname{ESR}(\mathrm{p}<0 \cdot 01), \operatorname{CRP}(\mathrm{p}<0.01)$, and fibrinogen $(\mathrm{p}<0.05)$. The only significant difference between those patients with an iritis and those with only pelvospondylitis was an elevated CRP in the iritis group $(\mathrm{p}<0.01)$. This suggests that a peripheral arthritis is the most important cause of an elevated ESR or APP in ankylosing spondylitis. Serum immunoglobulins were also measured and they showed a significant elevation of $\mathrm{IgA}$ in all 3 patient groups, there being no difference between each group. Serum IgG was raised only in those patients with an iritis or peripheral arthritis, the IgM levels being within the normal range for all patient groups.

The dominant lesion in ankylosing spondylitis (AS) is an inflammatory arthritis of the spinal and sacroiliac joints. However, it is complicated by peripheral arthritis in $50 \%$ of cases, iritis in $30 \%$, and aortitis in $5 \% .^{1}$ Clinical assessment of spinal disease activity is difficult because there are few reliable signs, and there is a need for a reliable laboratory measurement of disease activity.

In rheumatoid arthritis the erythrocyte sedimentation rate (ESR) is the commonly used laboratory measure of disease activity, and its level usually correlates with clinical assessment of disease activity. C-reactive protein (CRP), an acute-phase protein, has been found to respond to changes in clinical activity more closely than the ESR. ${ }^{2}$

In AS there is a poor correlation between clinical disease activity and the ESR. Even though it tends to be elevated early in the disease, often patients with florid spondylitis may have a normal ESR, and, conversely, clinically quiescent patients may have an elevated ESR. In AS the ESR has been regarded as an aid to diagnosis but of little value in prognosis and response to therapy. ${ }^{3}$ However, the ESR is a nonspecific test influenced by a large number of factors

Accepted for publication 15 October 1982. Correspondence to Professor G. S. Panayi. unrelated to inflammation, ${ }^{4}$ and it may be of greater value to measure acute-phase proteins.

Serum immunoglobulins have also been shown to be elevated in $\mathrm{AS}^{, 5-7}$ the most significant being an elevated $\operatorname{IgA}$. $\operatorname{IgA}$ levels have also been shown to correlate with a raised ESR and CRP, ${ }^{8}$ suggesting that they may have a role in the measurement of disease activity.

The aim of this study was to measure the acutephase proteins fibrinogen, C-reactive protein, $\alpha_{1}-$ antitrypsin, and the 9 th component of complement and immunoglobulins $\mathbf{G}, \mathbf{A}$, and $\mathrm{M}$, and to determine their correlation with clinical disease activity and extraspinal manifestations.

\section{Materials and methods}

Eighty patients who fulfilled the New York criteria for AS were studied. ${ }^{9}$ Their mean age was $42 \cdot 3$ years (range 22-67 years), with a mean disease duration of 13.9 years (range $1.4-36$ years). There were 17 female patients. Patients with spondylitis secondary to inflammatory bowel disease, psoriasis, or Reiter's disease were excluded from this study. All patients were rheumatoid-factor-negative. There were $\mathbf{5 0}$ controls who consisted of patients with degenerative 
joint disease or minor joint or soft tissue injuries, whose mean age was $39 \cdot 3$ years (range 19-60 years). There were 11 female controls.

Sixteen patients had only one assessment, 19 patients 2,17 patients 3,21 patients 4 , and 7 patients 5 or more, making a total of 231 assessments. The length of follow-up varied from 3 to 18 months.

Disease activity. This was evaluated on the basis of early morning stiffness, pain score, dosage of antiinflammatory medication, and the presence of a peripheral arthritis and/or iritis. Eleven patients had a peripheral arthritis and 8 an acute iritis when assessed. Comparisons were also made between 3 patients subgroups which consisted of pelvospondylitis only, pelvospondylitis with iritis, and pelvospondylitis with a peripheral arthritis.

Serum and plasma samples. Blood was taken at the time of assessment, the serum and plasma (in ethylene diamine tetra-acetic acid) being separated and aliquots stored at $-70^{\circ} \mathrm{C}$, being thawed only once.

Methods. The ESR was measured by the modified Westergren method. ${ }^{10}$ C-reactive protein, fibrinogen, $\alpha_{1}$-antitrypsin, 9th component of complement, and immunoglobulins $G, A$ and $M$ were measured by single radial immunodiffusion in agar with monospecific antisera (Behringwerke).$^{11}$

Statistics. Results were analysed by multiple linear regression and Student's $t$ test for independent means.

\section{Results}

Acute-phase proteins. When mean levels of acutephase proteins for each patient subgroup were examined, in the pelvospondylitis group there was a significant elevation of fibrinogen and the 9th component of complement (C9) $(\mathrm{p}<0.01)$ in comparison with the normal controls (table 1). The CRP levels were only marginally elevated $(p<0.05)$, and the ESR and $\alpha_{1}$-antitrypsin levels were not significantly different from the controls. However, the elevation of acute-phase proteins was more marked in the subgroup of patients with a peripheral arthritis or iritis in comparison with the controls. In both subgroups there was a significant elevation of CRP $(p<0 \cdot 01)$, fibrinogen, and C9 $(p<0.01$ for the iritis subgroup and $p<0.001$ for the peripheral arthritis subgroup), and $\alpha_{1}$-antitrypsin $(p<0 \cdot 05)$. The ESR was not elevated in the iritis subgroup, but was increased in those patients with a peripheral arthritis $(p<0 \cdot 01)$. Differences between the 3 patient subgroups were also noted. There was a significant difference between those patients with a peripheral arthritis and those with pelvospondylitis for the ESR, CRP, C9 $(p<0 \cdot 01)$, and fibrinogen $(p<0.05)$, the levels being

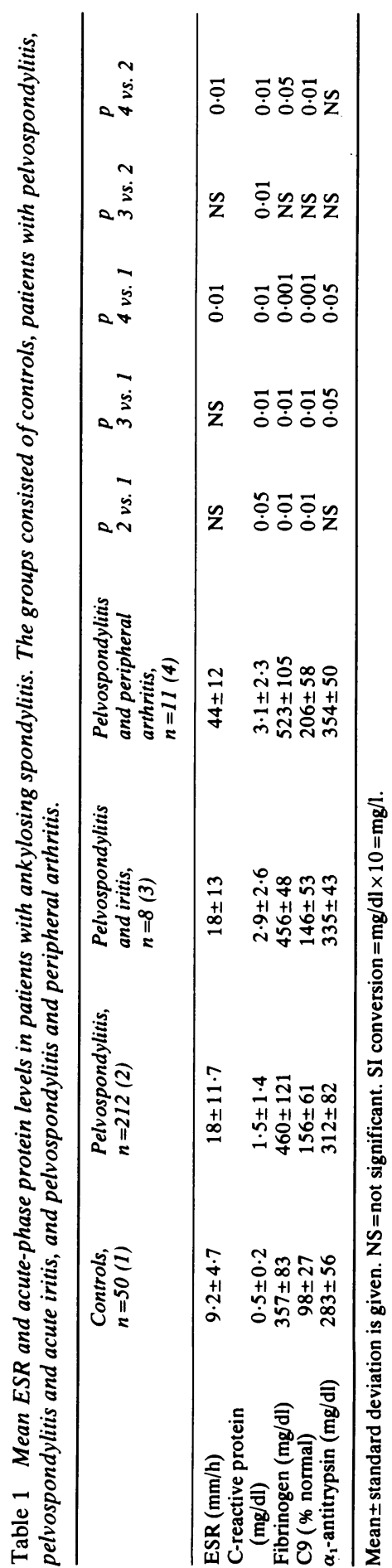


higher in the group with a peripheral arthritis. The differences between those with pelvospondylitis only and those also with iritis were significant only for CRP ( $p<0.01)$, this being higher in the iritis group.

Comparison between the subgroups with iritis and peripheral arthritis revealed a significant increase in the latter only for the ESR $(p<0.01)$ and C9 $(\mathrm{p}<0.05)$.

Serum immunoglobulins. The mean immunoglobulin $\mathrm{A}(\operatorname{Ig} \mathrm{A})$ level was significantly elevated in all 3 patient subgroups in comparison with the controls $(p<0.001)$, but there was no significant difference between the 3 patient subgroups (Table 2). In the patients with pelvospondylitis only, serum IgA concentration was $3.45 \pm 1.48 \mathrm{gm} / \mathrm{l}$ (mean \pm standard deviation) in those with a CRP greater than $1.5 \mathrm{mg} / \mathrm{dl}$ $(15 \mathrm{mg} / \mathrm{l})$ and $2 \cdot 54 \pm 1.32 \mathrm{~g} / \mathrm{l}$ when the CRP was less than $1.5 \mathrm{mg} / \mathrm{dl}(15 \mathrm{mg} / \mathrm{l})$. This difference was statistically significant $(p<0 \cdot 01)$, although absolute levels of IgA and CRP did not correlate. Immunoglobulin G (IgG) was significantly elevated only in patients with iritis $(p<0.05)$ or with peripheral arthritis $(p<0.02)$ in comparison with normal persons. There was no significant difference for mean IgG levels between the patient subgroups. Serum IgM levels were not significantly elevated. The ratio of $\operatorname{IgA}$ to $\operatorname{IgG}$ was significantly elevated in all 3 patient groups $(p<0.05)$, the normal ratio being 1.08 in normal controls, 1.43 in the pelvospondylitis subgroup, 1.52 in the patients with iritis, and 1.64 in those with peripheral arthritis. This disproportionate increase in IgA levels is also found in psoriasis and psoriatic arthritis but not in rheumatoid arthritis. ${ }^{12}$

Clinical disease activity. There were no correlations between the disease activity measurements of early morning stiffness, pain score, or dosage of antiinflammatory medication, and the acute-phase proteins or immunoglobulins.

Correlations between acute-phase proteins and immunoglobulins. For all 3 patient subgroups there were significant correlations between $C 9$ and CRP $(p<0.01), C 9$ and fibrinogen $(p<0.01)$, and CRP and fibrinogen $(p<0.05)$. In the patients with a peripheral arthritis there were additional correlations between IgG and $\operatorname{IgA}(\mathrm{p}<0 \cdot 01), E S R$ and CRP $(\mathrm{p}<0.01)$, and ESR and $\mathrm{C} 9(\mathrm{p}<0.05)$.

Longitudinal studies. When the results were examined longitudinally, the disparity between disease activity measurements and acute-phase proteins persisted. There were a few exceptions, however, in which they did correlate, but these were usually patients with a peripheral arthritis (data not shown).

\section{Discussion}

The acute-phase proteins (APP) are a group of nor-

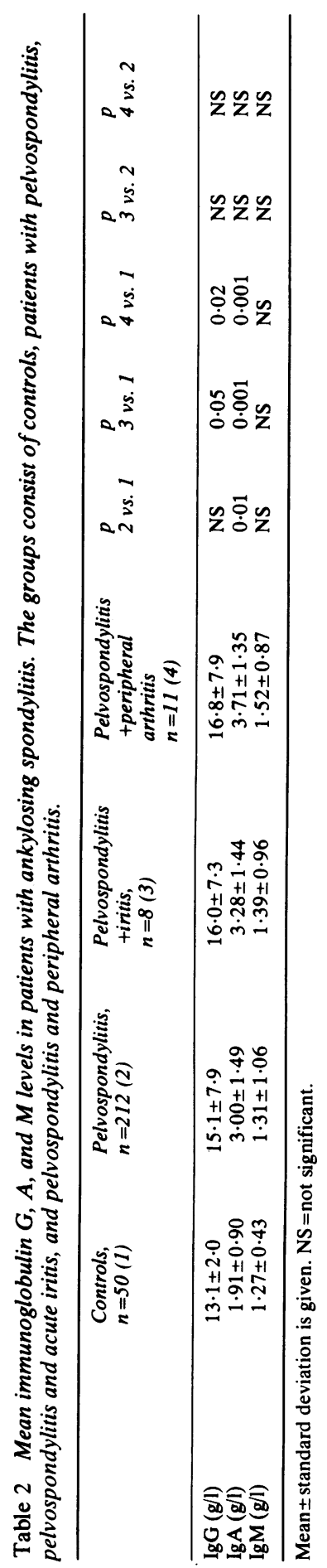


mal plasma proteins whose levels rise significantly during an inflammatory process. Stimuli for APP production include injury, surgery, bacterial infection, and administration of bacterial endotoxin. C-reactive protein (CRP), $\alpha_{1}$-antitrypsin $\left(\alpha_{1}\right.$-AT), and fibrinogen have often been used in assessing disease activity in man. ${ }^{13}$ Normally CRP is absent or present in very low levels in normal serum, is usually detectable in serum within 24 hours of an inflammatory stimulus, and disappears with resolution of the inflammation. ${ }^{14}$ Persistence of CRP therefore usually indicates persistence of inflammation. Fibrinogen and $\alpha_{1}$-AT levels also rise rapidly after an inflammatory stimulus, but, whereas $\alpha_{1}$-AT rapidly returns to normal levels, increased fibrinogen levels may persist for a long time after resolution of the inflammation. ${ }^{15}$ Animal studies have shown that increased concentrations of APP are proportional to the severity of tissue damage. ${ }^{16}$ The 9 th component of complement (C9) has only recently been recognised as an APP. ${ }^{17}$ Levels increase with turpentine-induced inflammation in animals ${ }^{18}$ and in some diseases C9 concentrations correlated with the ESR and $\alpha_{1}$-AT concentrations. ${ }^{1920}$

In this study there was no correlation between the APP levels and the clinical measurement of disease activity for the total patient group. A similar lack of correlation has been shown between clinical disease activity as measured by pain, and the ESR. ${ }^{21}$ This lack of correlation was also present in patients followed up longitudinally, only occasional patients showing a relationship between an APP and disease activity. The main reason for this lack of correlation is the difficulty in accurately assessing clinical disease activity in patients with only pelvospondylitis. Even though patients with a peripheral arthritis had higher mean levels of APP, there was not a significant correlation with disease activity.

The commonly used nonsteroidal antiinflammatory drugs (NSAID) do not influence the ESR or APP, ${ }^{22}$ so that their levels would more accurately reflect the degree of inflammation. In contrast to this, symptoms are significantly modified by NSAID medication, and this would give an erroneous clinical assessment of disease activity. In the pelvospondylitis subgroup there were correlations between the APP CRP, C9, and fibrinogen. This implies that the elevation of these 3 APPs could be more representative of the amount of inflammation than the clinical assessment.

The mean APP levels for the disease subgroups were interesting in that there was a marked difference between those with and without a peripheral arthritis. The ESR, CRP, fibrinogen, and C9 were significantly elevated in the peripheral arthritis group in comparison with those with only pelvospondylitis.
Cowling et al. ${ }^{23}$ found a correlation between ESR. CRP, and clinically assessed disease activity. This is in contrast to other reports that could not find an association between ESR and disease activity. One reason for this discrepancy might be that an important criterion in their classification of active disease was the presence of a peripheral arthritis. It is possible that the synovitis is responsible for the raised CRP and ESR rather than the pelvospondylitis.

Possibily because the synovitis produces a greater degree of inflammation than the pelvospondylitis it stimulates a greater APP response. It could also be a different type of inflammation, being the appropriate one to produce a significant APP response. In diseases in which several APP have been measured there is not always a simultaneous elevation of all APP. Examples of these observations are an elevation of haptoglobin, ceruloplasmin, and orosomucoid but not of $\alpha_{1}$-antitrypsin and CRP in systemic lupus erythematosus ${ }^{24}{ }^{25}$ and elevation of different APP in the various subgroups of Behçet's syndrome. ${ }^{26}$ This suggests that each APP requires a different type of inflammatory stimulus and could have a specific physiological function, and therefore in assessing inflammation in a disease several APP should be measured. Serial measurements in patients did not add any additional information about the relationship between APP and clinical disease activity.

A slightly different pattern of response was noted for the immunoglobulins in that the differences between the 3 disease groups were not as great as those for the APP. IgA is elevated in all groups, with higher levels in those with an iritis or peripheral arthritis. However, this difference is not significant, and absolute levels did not correlate with clinical disease activity. Several authors have shown an elevated $\lg \mathrm{A}$ in ankylosing spondylitis. ${ }^{5-8}$ Veys et al. ${ }^{5}$ did not find any correlation between serum $\operatorname{IgA}$ and a peripheral arthritis, ESR, CRP, subjective complaints, or a radionuclide scan of the spine and pelvis. However, 2 studies found the highest mean levels of serum IgA to be in those patients with active disease, as measured by an ESR greater than $15 \mathrm{~mm}$ in 1 hour or a CRP greater than $15 \mathrm{mg} / \mathrm{dl}(150 \mathrm{mg} / \mathrm{l}) .{ }^{\times 27}$ We also noted that in the pelvospondylitis group mean IgA levels were highest in those patients with a CRP greater than $15 \mathrm{mg} / \mathrm{dl}(150 \mathrm{mg} / \mathrm{l})$. Mucosal-associated lymphoid tissue is an important source of serum IgA. especially the polymeric fraction. The elevated serum $\operatorname{IgA}$ in ankylosing spondylitis suggests that the inciting antigen may be acting at a mucosal surface, the gastrointestinal tract being a possibility.

Mean serum IgG levels have also been shown to be highest in those patients with active disease as measured by an elevated ESR and CRP. ${ }^{\times 2}$ In our study the highest mean levels were associated with a 
peripheral arthritis. Most reports have found serum IgM levels to be within normal limits. ${ }^{5-8}$

In conclusion, the acute-phase protein levels distinguish between the patients with pelvospondylitis alone and pelvospondylitis with a peripheral arthritis. However, the problem in defining active disease in patients with only pelvospondylitis still remains. In our study the fibrinogen, C9, and CRP correlated with each other and probably more accurately reflect inflammation than clinical assessment. They may be a more reliable method for measuring disease activity in patients with ankylosing spondylitis.

We are grateful to Dr R. Grahame and Dr T. Gibson for allowing us to study some of their patients. This study was financed by a fellowship from the Special Trustees of Guy's Hospital for Dr Laurent and a programme grant from the Arthritis and Rheumatism Council.

\section{References}

1 Wright V, Moll J M L. Seronegative polyarthritis. Amsterdam: North Holland, 1976: 99-102.

2 McConkey B, Crockson R A, Crockson A R. The assessment of rheumatoid arthritis. A study based on the measurements of acute phase reactions. $Q J$ Med 1972; 41: 115-25.

3 Hart F D, Robinson K C, Allchin F M, Maclagan N F. Ankylosing spondylitis. $Q J$ Med 1949; 18: 217-34.

4 Ritzmann S E, Daniels J C. (1975) Serum protein abnormalities: diagnostic and clinical aspects. 1st ed. Boston: Little, Brown, 1975: 332-5.

5 Veys G M, Van Laeve M. Serum IgG, IgM and IgA levels in ankylosing spondylitis. Ann Rheum Dis 1973; 32: 493-6.

6 Kinsella T D, Espinoza L, Vasey F B. Serum complement and immunoglobulin levels in sporadic and familial ankylosing spondylitis. J Rheum 1975; 2: 308-13.

7 Kendall M J, Farr M, Williamson N. Serum immunoglobulins in ankylosing spondylitis. $\mathrm{Br}$ Med J 1973; ii: 172.

8 Cowling P, Ebringer R, Ebringer A. Association of inflammation with raised serum $\operatorname{IgA}$ in ankylosing spondylitis. Ann Rheum Dis 1980; 34: 545.

9 Bennett P H, Wood P H N, eds. In: Population studies of the rheumatic diseases. Amsterdam: Excerpta Medica, 1968: 456.

10 Belin D C, Morse E, Weinstein A. Whitter Westergren. The sedimentation rate re-evaluated. J Rheumatol 1981; 8: 331-5.

11 Mancini G, Carbonara H O, Heremans J F. Immunological quantification of antigens by single radial immunodiffusion. Immunochemistry 1965; 2: 235-54.
12 Laurent M R, Panayi G S , Shepherd P. Circulating immune complexes, serum immunoglobulins and acute phase proteins in psoriasis and psoriatic arthritis. Ann Rheum Dis 1981; 40: 66-9.

13 Koj A. Acute phase reactants. In: Allison A S, ed. Structure and function of plasma proteins. London: Plenum Press, 1974: 1: 73-132.

14 Pepys M B. C-reactive protein fifty years on. Lancet 1981; i: 653-7.

15 Wycott H D. Production of fibrinogen following an endotoxin injection. Pro Soc Exp Biol Med 1970; 133: 940-3.

16 Darcy D A. Granuloma weight and the $\alpha_{1}$ acute phase protein response in rats injected with turpentine. Br J Exp Pathol 1970; 51: 59-72.

17 Kawachi-Takahashi S, Tanaka K, Takahashi M, Kawashima T, Shimada K. Determination of C9 level by immunodiffusion. In Arch Allergy Appl Immunol 1975; 48: 161-70.

18 Takahushi M, Kawachi-Takahushi S, Yamamoto K. Synthesis of the ninth component of guinea pig complement (C9) in response to experimentally induced inflammation. Int Arch Allergy Appl Immunol 1974; 47: 887-93.

19 Ruddy S, Everson L K, Schurr P H, Austen K F. Haemolytic assay of the ninth complement component: elevation and depletion in rheumatic diseases. J Exp Med 1971; 134: 2595-755.

20 Kawachi-Takahashi S, Takahashi M, Kogune M, Kawashima T. Elevation of serum C9 level associated with Behçet's disease. Jpn J Exp Med 1974; 44: 485-9.

21 Kendall M J, Lawrence D S, Shuttleworth G R, Whitfield A G W. Haematology and biochemistry of ankylosing spondylitis. Br Med J 1973; i: 235-7.

22 McConkey B, Crockson R A, Crockson A P, Wilkinson A K. The effects of some anti-inflammatory drugs on the acute phase proteins in rheumatoid arthritis. $Q J$ Med 1973; 42: 785-91.

23 Cowling P, Ebringer R, Cawdell D, Ishii M, Ebringer A. C-reactive protein, ESR, and klebsiella in ankylosing spondylitis. Ann Rheum Dis 1980; 39: 45-9.

24 Becker G J, Waldburger M, Hughes G R V, Pepys M B. Value of serum C-reactive protein measurement in the investigation of fever in systemic lupus erythematosus. Ann Rheum Dis 1980; 39: 50-2.

25 Werner $M$. Serum protein changes during the acute phase reaction. Clin Chim Acta 1959; 25: 299-305.

26 Adinolfi $M$, Lehner $T$. Acute phase proteins and $C 9$ in patients with Behçet's syndrome and aphthous ulcers. Clin Exp Immunol 1976; 25: 36-9.

27 Calgunesi M, Swinburne L, Shinebaum R, Cooke E M, Wright V. Secretory IgA: immune defence pattern in ankylosing spondylitis and klebsiella. Ann Rheum Dis 1981; 40: 600-4. 